\title{
LVIII. Remarks on the structure and affinities of Cephalotus
}

\section{Robert Brown Esq. F.R.S.}

To cite this article: Robert Brown Esq. F.R.S. (1832) LVIII. Remarks on the structure and affinities of Cephalotus, Philosophical Magazine Series 3, 1:4, 314-317, DOI: 10.1080/14786443208647898

To link to this article: http://dx.doi.org/10.1080/14786443208647898

册 Published online: 01 Jun 2009.

Submit your article to this journal $₫$

Џ Article views: 2

Q View related articles $₫$ 
lectively, must have a prevailing tendency; and it follows from the direction of the needle, that this tendency, as it respects the positive currents, must be from the east, more or less towards the west.

It appears that the ores themselves, in some instances, possess opposite thermo-electric properties. The sulphurets of lead and of copper, for example, when partially heated in a very moderate degree, yielded positive electricity to the less heated part; whereas in the case of sulphuret of iron, it was yielded from the latter to the former. When two of these ores were respectively placed in contact with each other at different temperatures, the sulphuret of lead was always positive with respect to the other two, whether it was at a higher or lower temperature than they were; and the sulphuret of copper was, when heated, positive with regard to iron pyrites, but negative when the temperature of the latter was the greater. In some instances the nature of the electricity became reversed before the heated ore had entirely cooled; this occurred when lead or copper ore was placed in contact with iron pyrites at an inferior temperature.

These different thermo-electric properties of metallic substances seem to throw some light on the cause of opposite currents in mineral veins, and are, perhaps, connected with the periodical variation of the needle.

Several observations have been made in the mines of Cornwall on the intensity of the earth's magnetism, from which it is to be inferred, that if at the greatest accessible depths it differ at all from the intensity at the surface, the difference is very inconsiderable, and that therefore the principal source, or cause of the terrestrial magnetism, must be far removed from us, so far indeed as to require powerful electrical currents to produce the effects observable at the surface.

LVIII.Remarks on the Structure and Affinities of Cephalotus. By Robert Brown, Esq. F.R.S. \&c.* *

$\mathrm{N}$ the Botanical Appendix of Captain Flinders's Voyage to Terra Australis, a figure and description of Cephalotus follicularis are given, in some respects more complete than those of M. Labillardière, by whom this remarkable plant, a native of the south-west coast of New Holland, was first published. Both accounts, however, are equally imperfect with regard to the fruit; and my principal object in the present communication is to supply that deficiency.

My earliest knowledge of the ripe fruit of Cephalotus was

* Communicated by the Author. 
obtained from a single specimen, sent in 1815 by M. Lechenault, who had found the plant in February 1803 near the shores of King George's Sound, where I had gathered it in a less advanced state in the begiming of January 1802.

I have, however, more recently, received numerous specimens with ripe seeds from Mr. William Baxter, who collected them also at King George's Sound in 1829.

Cephalotus was introduced in 1823 from the same place by Capt. King, into His Majesty's Botanic Garden at Kew, where it flowered repeatedly, and ripened seeds from which several plants have been raisecl. A figure of one of these with expanded flowers, but still without fruit, has lately been published by Dr. Hooker in the Botanical Magazine; and a plant brought also from King George's Sound in 1829 by Mr. William Baxter is now in flower in Mr. Knight's nursery.

The following account of the ripe fruit will serve as a supplement to the description of the plant which $I$ have given in the work referred to.

A kenia membranacea, insecta parva alis conniventibus quodammodò referentia, perianthio parùm aucto staminibusque persistentibus cincta, iisque sesquilongiora, ferè distincta, ipsâ basi, ubi receptaculo communi inserta, post separationem intùs aperta ibique è membranâ simplici crassiusculâ imberbi nitente formata; suprà clausa et è duplici membranâ conflata; harum exterior densè barbata, pilis longis, strictis, acutis, deflexis, stylo persistenti brevi arctè reflexo rostrata : membrana seu lamella interior tenuis, intùs quandoque dehiscens.

SeMen unicum (rarissimè duo), basi cavitatis membranæ, interioris insertum, oblongo-ovale, teres, funiculo umbilicali brevi juxta basin affixum. Integumentum duplex: Testa membranacea laxiuscula, raphe tenui laterali et apice chalaz $\hat{a}$ parvâ insignita: Membrana interior tenuis separabilis. Albumen semini conforme, album, carnosum, subfiiabile, è materiâ oleosâ cum granulis minutis mixtâ constans.

Eмвиуо parvus, in basi axeos albuminis, teretiusculus, albus, rectus, albumine $1-5$ ies brevior. Cotyledones breres, plano-convexæ. Radicula teres, basin seminis attingens.

Receptaculum commune fructûs : tuberculum centrale, parvum, brevissimum, subcylindraceum, cujus lateribus bases apertæ akeniorum adnatæ sunt, apice convexiusculo barbato.

From this description, especially of the embryo, it is evident that Cephalotus must be removed from Rosaceæ, to which it had been referred by M. Labillardière; and also, though not with much confidence, in the account which I published in 1514. M. de Jussieu, indeed, in 1815, proposed to exclude $2 \mathrm{~S} 2$ 
it from Rosaceæ and append it to Crassulaceæ; and the structure of the seed, as well as of the folliculi or akenia, and even their insertion on the minute central receptacle or axis, may seem to confirm the correctness of this approximation.

Cephalotus, however, still appears to me sufficiently remote from every natural order at present established, to entitle it (like Philydrum* and Brunonia $\dagger$ ), now that its structure is completely known, to rank as a distinct family which may be called Cephalotere, and which may be placed between Crassulaceæ and Francoaceæ; differing from both in being apetalous, in the valvate æstivation of the perianthium, and in many characters of inferior importance: from Crassulaceæ also in its minute embryo and more copious albumen; and from Francoaceæ in the absence of barren stamina and in the pistilla being monospermous and apparently distinct.

The most striking peculiarity of Cephalotus consists in the conversion of a portion of its radical leaves into Ascidia or pitchers. But as ascidia in all cases are manifestly formed from or belong to leaves, and as the various parts of the flower in Phænogamous plants are now generally regarded as modifications of the same organs, the question is naturally suggested, how far the form and arrangement of the parts of fructification agree in those plants whose leaves are capable of producing ascidia or pitchers. The four principal, and indeed the only genera in which pitchers occur, are Nepenthes, Cephalotus, Sarracenia, and Dischidia, and the few other somewhat analogous cases, consisting of the conversion of bracteæ or floral leaves into open cuculli, are found in Marcgravia and two other genera of the same natural family.

The only thing common to all these plants is, that they are Dicotyledonous.

It may also be remarked, that in those genera in which the Ascidia have an operculum, namely Nepenthes, Cephalotus, and Sarracenia, they exist in every known species of each genus, and the structure of these genera is so peculiar that they form three distinct natural families; while in Dischidia, whose pitchers are formed without opercula, these organs are neither found in every species of the genus, nor in any other genus of the extensive natural order to which it belongs.

The striking resemblance in most points of the Ascidia of Cephalotus to those of Nepenthes, leads to a comparison in the first place of these two genera. But although both are apetalous, and in the parts of the flower deviate from the quinary or prevailing number in Dicotyledones, yet they differ

* Flinders's Voyage, vol. ii. p. 578.

+ Transact. Linn. Soc. vol. xii. p. 132. 
in so many other important characters that they cannot be considered as nearly related.

The place of Nepenthes in the natural series $I$ have long since*, in my account of Rafflesia, suggested to be near Aristolochiæ or Asarinæ, without, however, intending to include it in that family.

This approximation was adopted by M. Ad. Brongniart, who, however, went further, having absolutely referred Nepenthes to Cytineæ.

The union of plants so utterly unlike in appearance and œconomy, and so different, it may be added, in many of their most important characters, seems to have been generally regarded as somewhat paradoxical; and accordingly Protessor Link, in 1829, has established Nepenthes as a section or tribe of Aristolochiæ, and Dr. Bartling and Mr. Lindley, in 1830, have considered it as forming a distinct natural family.

'To the numerous and obvious distinctions between Cytineæ and Nepenthes may be added the no less important differences in their internal structure. For while Cytines, like most, perhaps all, other plants parasitical on roots, are destitute of spiral vessels, Nepenthes exhibits these vessels in the greatest degree of development and abundance, and also produces them in parts in which they are hardly to be met with in any other dicotyledonous plant.

Thus, in addition to the dense circle or stratum of spiral vessels existing in the stem between the outer parenchyma and the wood, they are found also singly or scattered in the pith, in the loose parenchyma situated between the wood and the bark, if it may be so called, even in the fibres of the root, and everywhere in the substance of the leaves, the pitchers, calyx and capsules. And between these solitary or scattered spiral vessels, which are often of considerable lemgth, and those forming the stratum or circle externally bounding the wood and existing in the veins of the leaves, no essential difference in structure will I believe be found. In these points there is little resemblance between Nepenthes and Cephalotus, in the internal structure of which last there is nothing unusual.

Between the parts of fructification of Nepenthes or Cephalotus and Sarracenia, there is still less analogy, and it is obviously unnecessary to compare in this respect any of these genera with Dischidia.

September 25 th, 1832.

* Transact. Linn. Soc, vol, xiii. p. 219. 